\title{
Perception and Choice of Substratum by Epifaunal Amphipods Associated with Seagrasses*
}

\author{
A. W. Stoner \\ Harbor Branch Institution, Inc., RR 1, Box 196-A, Fort Pierce, Florida 33450, USA
}

\begin{abstract}
Laboratory experiments showed that the three epifaunal amphipods Cymadusa compta, Grandidierella bonnieroides, and Melita elongata, normally associated with seagrasses, are capable of detecting small differences in the density of seagrass and actively select areas of high blade density. When different seagrass species - Thalassia testudinum, Syringodium filiforme, and Halodule wrightii - were offered with equal blade biomass, $H$. wrightii was selected due to its high ratio surface area: biomass. When offered equal surface area all three amphipod species were randomly distributed among the seagrass species, confirming the hypothesis that surface area is the habitat characteristic chosen. It was concluded that blade surface area of macrophytes provides the best estimate of habitat complexity in seagrass meadows. The surface area relationship also held for C. compta when the highly branched red alga Gracilaria foliifera was used as a substratum. Degree of habitat selectivity by the three species of amphipods was related to known differences in vulnerability to predation by Lagodon rhomboides. It is concluded that habitat preference and biological interactions must both be examined to fully understand distributional patterns in seagrass epifauna.
\end{abstract}

\section{INTRODUCTION}

Physiological tolerances and morphological constraints limit the distribution of a species within the ultimate boundaries of its geographic range. Two other factors, however, further regulate local patterns of distribution and abundance of an animal: habitat preference and interactions such as competition and predation with other animals. In recent years the vast majority of experimental studies in marine habitats concerning animal distribution have dealt with the effects of predation and competition (e. g. Dayton, 1971; Connell, 1972; Paine, 1974; Menge and Sutherland, 1976; Young et al., 1976; Virnstein, 1977; Young and Young, 1978; Nelson, 1979 a, b). Few studies have tested for habitat preference in motile macrobenthic invertebrates (Giles and Zamora, 1973; Van Dolah, 1978) although reports on habitat associations are widespread in the literature. Faunal associates of particular marine algae (Sloane et al., 1961; Hagerman, 1966; Norton, 1971; Fenwick, 1976; Moore, 1978) and seagrasses (Kita and Harada, 1962; O'Gower and Wacasey, 1967; Nagle, 1968; Santos and Simon, 1974; Stoner, in prep. a, b) have frequently been reported, but only Barry (1974) has tested for active preference

\footnotetext{
- Contribution No. 181 of the Harbor Branch Foundation, Inc.
}

by animals for particular macrophytes or for the cues which attract them to certain plant substrata.

The present study was designed to test the habitat preferences of epifaunal amphipods when offered three different seagrass species and a highly branched red alga. Because of differences in the ratios surface area to biomass among the plants, experiments were designed to test whether amphipod habitat selectivity was based on plant biomass or surface area. Adaptive significance of habitat selectivity in epifaunal amphipods is considered in relation to predatory behavior of major amphipod consumers.

\section{METHODS AND MATERIALS}

\section{Experimental Organisms}

Three gammaridean amphipod species were used in the habitat experiments: Cymadusa compta (Amphitoidae), Grandidierella bonnieroides (Corophiidae), and Melita elongata (Melitidae). Animals used in the experiments were collected in seagrass meadows of the Indian River lagoon, Florida (USA), by placing standard minnow traps filled with cotton netting in the field. Amphipods taken from traps were sorted to 
species and maintained in 20-1 indoor aquaria. Food in the form of seagrass, algae, and detritus was provided.

Seagrasses used in the experiments were Halodule wrightii, Syringodium filiforme, and Thalassia testudinum. Prior to experimentation, however, natural monospecific stands of each of the seagrasses were sampled in October, 1979 to provide an estimate of natural standing crop values. Seagrass standing crop was determined for beds spanning a full range of blade density in Indian River lagoon just north of the Harbor Branch Foundation, Inc. Blades were counted and measured for surface area, wet weight and dry weight. For determination of surface area, blades of $H$. wrightii and $T$. testudinum were considered to be rectangular surfaces with no thickness and blades of $S$. filiforme were measuered as cylinders. Eight 15 by $15 \mathrm{~cm}$ quadrats of each seagrass species were measured and weighed to provide equations which describe the blade-density biomass-surface-area relationships. One red algae, Gracilaria foliifera (Gracilariaceae), was also measured to determine the biomass surface-area relationship. After taking wet weight, four natural clumps of $G$. foliifera were measured for surface area. The complex branches of the alga were cut into simple cylinders and measured with an ocular micrometer. Total surface area of the plant was considered to be the summation of the area of individual cylinders. After measuring, all macrophyte samples were dried at $90^{\circ} \mathrm{C}$ to constant weight.

\section{Experiments}

All experiments were conducted in glass aquaria (30 $\times 30 \mathrm{~cm}, 45 \mathrm{~cm}$ high). The bottoms of the aquaria were covered with an 8-cm deep layer of clean, white sand (median grain diameter $=\sim 0.4 \mathrm{~mm}$ ). Fresh seagrass blades, free of epiphytes, were planted in the four 15 by $15 \mathrm{~cm}$ corners of the aquaria leaving approximately $2 \mathrm{~cm}$ of bare sand between different experimental stands. Clumps of Gracilaria foliifera were placed on top of the sand. After planting the macrophytes, seawater in the tanks was aerated for 30 to $60 \mathrm{~min}$ prior to the addition of amphipods. To prevent circulation of water, tanks were not aerated or filtered during experimental runs. 24 individuals of a single species were added to the center of the aquaria and left undisturbed overnight (16 to $24 \mathrm{~h}$ ). The resulting density (24 ind. 900 $\mathrm{cm}^{-2}$ ) approximated normal field conditions (Nelson et al., unpubl.; Stoner, in prep. a). At the end of an experimental period, a clear plexiglass divider was used to separate the four quadrants of the experimental chamber. The macrophytes were then carefully removed from the individual compartments and searched for amphipods. Early runs showed that subadult amphipods did not differ from adults in habitat preference; therefore, on most runs adults were used to facilitate the search process. All runs were made with salinity between 25 and $26 \% \mathrm{~S}$ and water equilibrated to room temperature $\left(18.0^{\circ}-24.6^{\circ} \mathrm{C}\right)$, approximating field conditions. Aquaria were subject to natural photoperiod. Three replicates for each treatment were run.

Four types of experiments were conducted: (1) Amphipods of each species were tested for their preferences of seagrass biomass using single seagrass species. Based on the ratio wet weight to dry weight, macrophytes were planted using $0.5,1.0,2.0$, and $4.0 \mathrm{~g}$ dry weight in the four quadrants of the experimental

Table 1. Biomass, total surface area and approximate number of seagrass blades $225 \mathrm{~cm}^{-2}$ quadrant used in experiments with the four plant species listed. - not determined

\begin{tabular}{|c|c|c|c|c|}
\hline Quantity & H. wrightij & S. filiforme & $T$ testudinum & G. foliffera \\
\hline & \multicolumn{4}{|c|}{ Low biomass experiments } \\
\hline Biomass (g dry wt) & 0.50 & 0.50 & 0.50 & - \\
\hline Surface area $\left(\mathrm{cm}^{2}\right)$ & 316 & 137 & 257 & - \\
\hline \multirow[t]{2}{*}{ Approx. No. blades } & 125 & 40 & 10 & - \\
\hline & \multicolumn{4}{|c|}{ High biomass experiments } \\
\hline Biomass (g dry wt) & 2.00 & 2.00 & 2.00 & 2.00 \\
\hline Surface area $\left(\mathrm{cm}^{2}\right)$ & 1245 & 537 & 1015 & 542 \\
\hline \multirow[t]{2}{*}{ Approx. No. blades } & 500 & 130 & 50 & - \\
\hline & \multicolumn{4}{|c|}{ Low surface-area experiments } \\
\hline Biomass (g dry $w t$ ) & 0.48 & 1.11 & 0.59 & - \\
\hline Surface area $\left(\mathrm{cm}^{2}\right)$ & 300 & 300 & 300 & - \\
\hline \multirow[t]{2}{*}{ Approx. No. blades } & 125 & 80 & 15 & - \\
\hline & \multicolumn{4}{|c|}{ High surface-area experiments } \\
\hline Biomass ( $g$ dry $w t)$ & 1.45 & 3.35 & 1.77 & 3.32 \\
\hline Surface area $\left(\mathrm{cm}^{2}\right)$ & 900 & 900 & 900 & 900 \\
\hline Approx. No. blades & 350 & 220 & 42 & - \\
\hline
\end{tabular}


tanks. (2) Amphipods of each species were tested for preferences among the three different seagrass species presented in equal biomass. Two biomass levels were used: 0.5 and $2.0 \mathrm{~g}$ dry weight of each species. In each case one quadrant contained no plants. (3) Preferences in each amphipod species were examined when the three seagrass species were offered equal total surface area. Again, two levels were tested: 300 and $900 \mathrm{~cm}^{2}$ in total blade surface area. (4) After the previously described experiments were run, experiment Types 2 (equal biomass) and 3 (equal surface area) were repeated with Gracilaria foliifera replacing the bare sand substrate to test whether or not a macrophyte structurally different from spermatophytes would elicit responses by amphipods different from those found with seagrasses. Tests with $G$. folififera as substratum were not conducted with Grandidierella bonnieroides as the amphipod is not generally an algal associate in Indian River lagoon (Stoner, unpubl.) and because of inability to obtain sufficient numbers of individuals. Data on biomass, surface area, and approximate number of macrophyte blades used in experiment Types 2, 3, and 4 are provided (Table 1).

\section{RESULTS}

Differences in surface area: biomass relationships among the macrophytes employed in this study (Fig. 1) permitted the testing of substratum perception. Halodule wrightii with thin, narrow blades had the highest ratio surface area: biomass at $715 \mathrm{~cm}^{2} \mathrm{~g}^{-1} \mathrm{dry}$ weight. For Thalassia testudinum the ratio was $515 \mathrm{~cm}^{2}$ $\mathrm{g}^{-1}$ dry weight; for Syringodium filiforme, $258 \mathrm{~cm}^{2} \mathrm{~g}^{-1}$ dry weight. The red alga Gracilaria foliifera had a

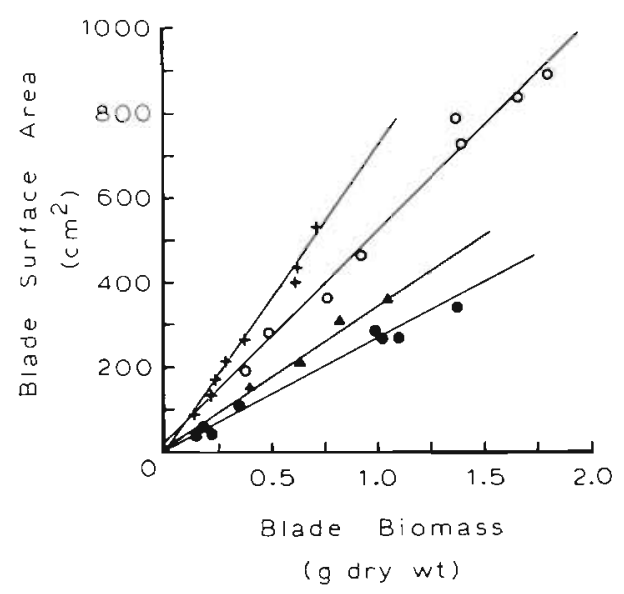

Fig. 1. Blade-surface-area to blade-biomass relationships for three seagrasses and a red alga collected in the Indian River lagoon, Florida. Open circles: Thalassia testudinum; closed circles: Syringodium filiforme; crosses: Halodule wrightii; triangles: Gracilaria foliifera

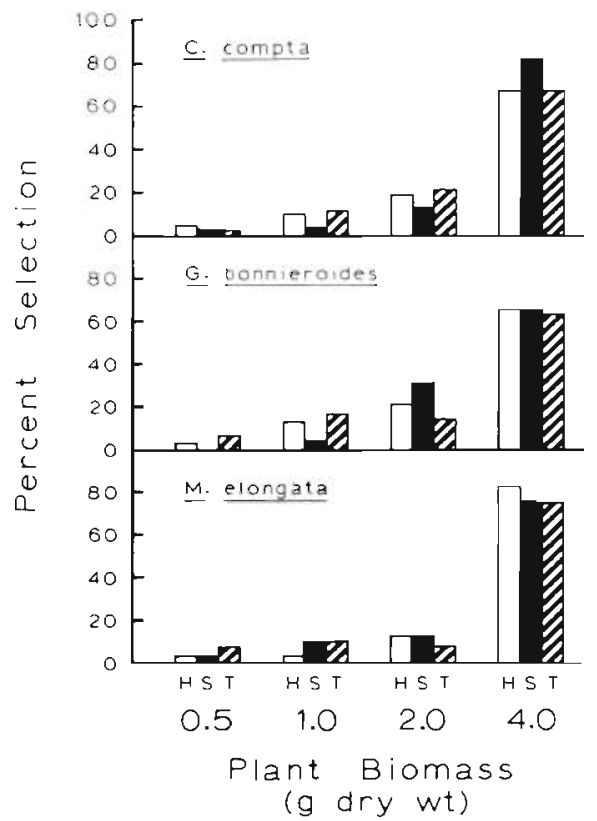

Fig. 2. Habitat selectivity by three epifaunal amphipods shown as a function of macrophyte biomass. Three different seagrasses were tested individually: Halodule wrightii $(\mathrm{H})$, Syringodium filiforms ( $\mathrm{S}$ ), and Thalassia testudinum (T). Each column represents three runs, involving 24 amphipods per run

value near the seagrass $S$. filiforme at $272 \mathrm{~cm}^{2} \mathrm{~g}^{-1}$ dry weight; both have cylindrical branches of approximately the same diameter.

All three amphipod species showed significant preferences for seagrass with high biomass, regardless of macrophyte species (Chi-square test, $p<.0005$, for all treatments) (Fig. 2). Over two-thirds of the amphipods were found to be associated with seagrass plots with the highest biomass; however, an examination of the Chi-square values (Table 2) shows that the preference for high density seagrass was strongest in Melita elongata, and generally weakest in Grandidierella bonnieroides.

Experiments which included different seagrasses and a bare sand substratum showed that, for all three amphipod species, vegetated substrata were preferred

Table 2. Chi-square values used to test for departure from randomness in the distribution of amphipods over substrata with different seagrass biomasses. Three seagrasses and three amphipods were tested. All Chi-square values were significant $(p<.0005)$

\begin{tabular}{|lrcc|}
\hline & \multicolumn{3}{c|}{ Seagrasses } \\
Amphipods & H.wrightii & S.filiforme & T. testudinum \\
\hline C. compta & 66.83 & 123.54 & 72.11 \\
G. bonnieroides & 62.24 & 73.89 & 51.86 \\
M. elongata & 129.96 & 100.66 & 96.17 \\
\hline
\end{tabular}




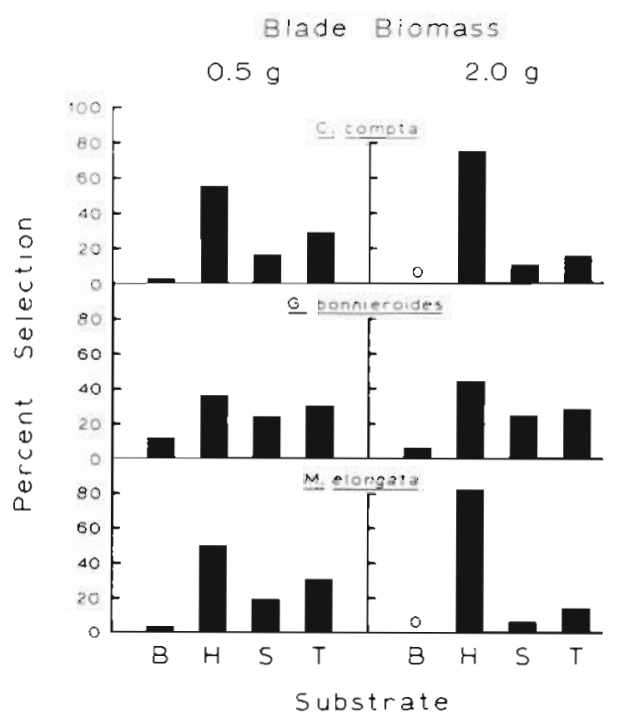

Fig. 3. Habitat selectivity by three epifaunal amphipods for three seagrasses and a bare sand substratum. B: bare substrate; $\mathrm{H}$ : Halodule wrightii; $\mathrm{S}$ : Syringodium filiforme; $\mathrm{T}$ : Thalassia testudinum. Seagrasses were tested in two densities with equal biomass, 0.5 and $2.0 \mathrm{~g}$ dry wt

over the bare sand quadrant (Figs 3 and 4) (Chi-square test: Table 3), although substantial numbers of Grandidierella bonnieroides were found on the sand quadrant. More importantly, when seagrasses of equal biomass were tested, statistical tests for randomness (eliminating the bare sand substratum from the analyses) revealed that Cymadusa compta and Melita elongata demonstrated definite preferences for Halodule wrightii as a substratum (Fig. 3) (Chis-quare test: Table 3). Excluding bare sand, Syringodium filiforme was selected by the fewest number of individuals, and Thalassia testudinum was intermediate. Although the trends were the same for $G$. bonnieroides

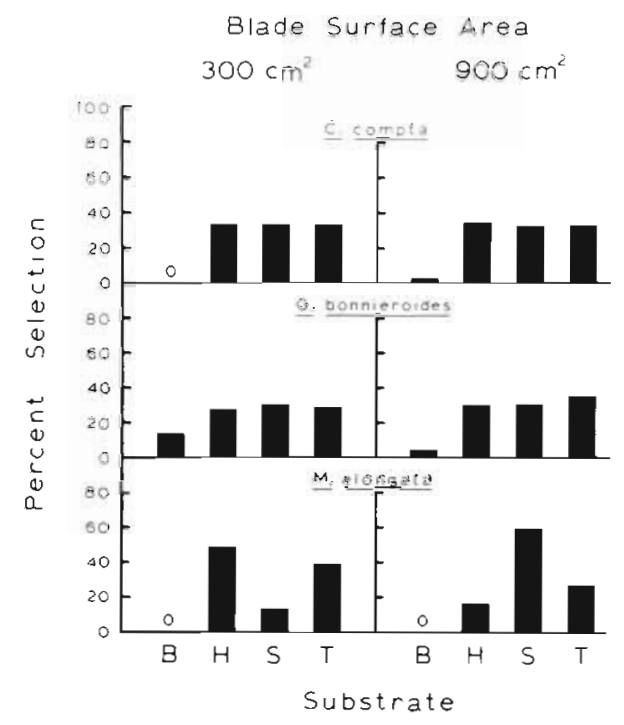

Fig. 4. Habitat selectivity by three epifaunal amphipods for three seagrasses and a bare sand substratum. B: bare substrate; $\mathrm{H}$ : Halodule wrightii; S: Syringodium filiforme; $\mathrm{T}$ : Thalassia testudinum. Seagrasses were tested in two densities with equal surface area, 300 to $900 \mathrm{~cm}^{2}$

in the equal biomass experiments, preferences for seagrass species as indicated by Chi-square tests were not significant for that species. In all cases, however, preference for $H$. wrightii was strongest when seagrass was provided in high biomass $(2.0 \mathrm{~g})$.

When the three seagrass species were planted with equal surface area the results (Fig. 4) were quite different from those found with equal biomass. Again, significantly fewer amphipods selected the bare sand quadrant of the tanks, but Cymadusa compta and Grandidierella bonnieroides showed no preference for seagrass species in either high or low surface area conditions (Chi-square test: $\mathrm{p}<.05$ ). Melita elongata,

Table 3. Chi-square values used to test for departure from randomness in the distribution of amphipods over three different seagrass species and a bare sand substratum. Values were calculated with and without numbers of animals on the sand substratum (d.f. $=3$ and 2 , respectively)

\begin{tabular}{|c|c|c|c|c|}
\hline \multirow[b]{2}{*}{ Amphipods } & \multicolumn{2}{|c|}{ Low biomass expt } & \multicolumn{2}{|c|}{ High biomass expt } \\
\hline & Incl.sand & Excl.sand & Incl.sand & Excl.sand \\
\hline C. compta & $44.09 \cdots$ & $17.51 \cdots$ & $93.76^{\cdots} \cdot$ & $53.32 \cdots$ \\
\hline G. bonnieroides & $8.54^{\circ}$ & 1.23 & $16.94^{\cdots}$ & 4.20 \\
\hline \multirow[t]{2}{*}{ M. elongata } & $31.14^{\cdots}$ & $9.91^{\circ}$ & $121.33^{\cdots} \cdot$ & $73.00 \cdots$ \\
\hline & \multicolumn{2}{|c|}{ Low surface-area expt } & \multicolumn{2}{|c|}{ High surface-area expt } \\
\hline Amphipods & Incl sand & Excl.sand & Incl.sand & Excl.sand \\
\hline C. compta & $23.00 \cdots$ & 0.00 & $21.11 \cdots$ & 0.03 \\
\hline G. bonnieroides & $8.17^{\circ}$ & 0.11 & $15.09^{\cdots}$ & 0.29 \\
\hline M. elongata & $43.65 \cdots$ & $14.98^{\cdots}$ & $51.48 \cdots$ & $21.11 \cdots$ \\
\hline \multicolumn{5}{|c|}{$\cdot=p<.05 ; \cdots=p<.005 ; \cdots=p<.0005$} \\
\hline
\end{tabular}


on the other hand, did show preference for seagrass species: for Halodule wrightii and Thalassia testudinum in the low surface area treatment (Chi-square test: $p<.005$ ) and for Syringodium filiforme in the high surface area treatment (Chi-square test: $p<$ .0005). In conditions of uniform surface area of macrophytes, however, $M$. elongata was found to aggregate, often the 6 to 10 individuals on a single seagrass blade. Out of 6 runs with $M$. elongata the majority of amphipods were always found on a single species of seagrass, twice on each of the three species. The exact point of aggregation appears to have been random. Apparent preference for a particular seagrass quadrant was an artifact of aggregation by the amphipod species.

In a final set of experiments the red alga Gracilaria foliifera was provided as a fourth macrophyte substratum in addition to seagrasses instead of a bare sand quadrant. Cymadusa compta showed preference for Halodule wrightii and Thalassia testudinum when equal biomass $(2.0 \mathrm{~g})$ of the three seagrasses and $G$. foliifera was offered (Chi-square test: $p<.005$; Fig. 5), again selecting the macrophytes with the highest ratio surface area: biomass. When the four plants were provided with equal surface area $\left(900 \mathrm{~cm}^{2}\right), C$. compta showed no macrophyte preference (Chi-square test: $p$ $<.05 ;$ Fig. 5). On the other hand: Melita elongata preferred $G$. foliifera as a habitat over all of the seagrasses regardless of experimental treatment, equal biomass or equal surface area (Chi-square test: $p<$ .0005 ; Fig. 5).

\section{DISCUSSION}

Small, cryptic animals such as amphipods are frequently found to be most abundant on highly complex habitats (e. g. Stoner, in press) and in recent studies of seagrass associates, habitat complexity was equated with macrophyte biomass (Heck and Wetstone, 1977). I have shown in this study that epifaunal amphipods which normally inhabit seagrass meadows are capable of perceiving habitats with relatively small differences in the biomass of a single seagrass species and rarely choose unvegetated habitats. However, the amphipods actively select certain species of seagrass when equal biomass of each is provided. The hypothesis that macrophyte surface area, not biomass, is the primary cue for habitat selection by epifaunal amphipods could be tested since the blades of Halodule wrightii, Syringodium filiforme, and Thalassia testudinum have large differences in their ratios surface area: biomass. When provided with equal total surface area all three amphipod species showed no selectivity for particular seagrass species, despite large differences in total

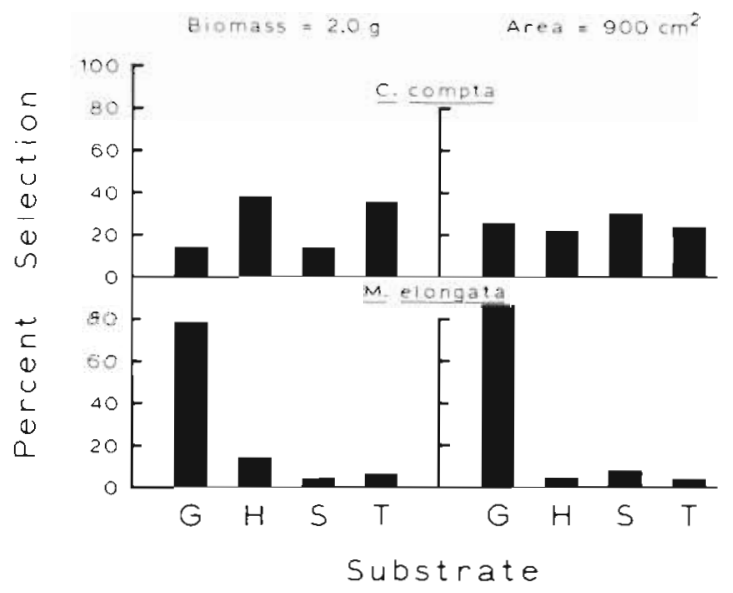

Fig. 5. Habitat selectivity by two epifaunal amphipods for three seagrasses and a red alga. Macrophytes were tested with equal biomass ( $2.0 \mathrm{~g}$ dry wt) and with equal surface area $\left(900 \mathrm{~cm}^{2}\right)$. G: Gracilaria foliifera; $\mathrm{H}$ : Halodule wrightii; S: Syringodium filiforme; T: Thalassia testudinum

biomass values (i. e. distribution over the three grasses did not diverge from that predicted for random processes). Comparing experiments employing equal plant biomass and equal plant surface area showed that surface area, not biomass, was the characteristic of seagrass plots selected by epifaunal amphipods.

The importance of plant surface area to epifaunal associates has long been recognized by researchers working with plant-animal relationships in freshwater, although no experimental work is known to this author. Freshwater researchers found that plant associates were generally most numerous and most diverse on submerged plants with greatest leaf division (Krecker, 1939; Andrews and Hasler, 1943; Rosine, 1955), which was directly related to leaf surface area. More recently, Harrod (1964) found differences in the number of animals supported per unit surface area among different freshwater macrophytes, but differences in periphyton and chemical nature of the macrophytes were proposed as explanations.

In the present study, surface area relationships clearly explained the choice of seagrass substrata by amphipods, but Melita elongata showed a definite preference for the red alga Gracilaria foliifera over seagrasses, suggesting that plants of grossly different tissues or habit may be differentially selected by some marine epifauna. Such habitat preferences probably relate to the life history, food habits and predators of individual animals. For example, Keith (1971) concluded that the amphipod Caprella californica demonstrated preference for bryozoans over algae as a substratum because of cryptic adaptations.

Since food and space are probably not limiting to epifauna in seagrass meadows (Heck and Wetstone, 1977), the adaptive significance of habitat choice by 
epifaunal amphipods may be related to behavior of the dominant amphipod consumers in seagrass beds. In analyses of the food habits and abundance of pinfish Lagodon rhomboides, (Stoner, 1979 a, b, in press), I concluded that this fish was the most important consumer of epifaunal amphipods in Apalachee Bay, Florida. Young et al. (1976) and Nelson (1979b) arrived at similar conclusions for pinfish in seagrass beds in southern Florida and North Carolina, respectively. Based on my recent experimental study of predatory behavior of $L$. rhomboides in the three seagrass species (Stoner, unpubl.), most of the patterns in habitat selection found in the present study can be shown to have adaptive significance. Predatory efficiency on the amphipods Melita elongata and Cymadusa compta was inversely related to macrophyte biomass in all seagrass species examined. The ability of an amphipod to find seagrasses in high density is, therefore, adaptively advantageous.

Differences in vulnerability to pinfish predation provide a plausible explanation for strong preference for high density seagrass by Melita elongata, an intermediate degree of preference in Cymadusa compta and lowest selectivity in Grandidierella bonnieroides. Under all conditions where seagrasses were present, $M$. elongata was preferred as prey over $C$. compta by 60-mm pinfish (Stoner, unpubl.) and G. bonnieroides was rarely consumed in Indian River lagoon (Stoner, unpubl.). Specific behavioral characteristics of the amphipods observed during the present study probably determine relative vulnerability to predation: $M$. elongata is more motile than the other two species making it more easily detected by visual predators, and it tends to aggregate, making location of $M$. elongata a highly profitable discovery for the predator. C. compta is more cryptic, both in behavior and in pigmentation, than $M$. elongata and does not aggregate. G. bonnieroides is also cryptic in color and in behavior, and frequently rests on the sediment or makes shallow burrows, further reducing its vulnerability to a visual predator such as Lagodon rhomboides. Predation experiments also showed that predatory efficiency by $L$. rhomboides was higher in Halodule wrightii, than in Thalassia testudinum or Syringodium filiforme when provided in equal biomass (Stoner, unpubl.). One might predict, therefore, that amphipods would show preference for $T$. testudinum and $S$. filiforme. Because preferences for particular seagrass species were not found, it might be hypothesized that the amphipods are incapable of perceiving differences among seagrasses. Major differences in the gross morphology of the three seagrasses, however, would appear to make this hypothesis an unplausible explanation. Preference of $M$. elongata for Gracilaria foliifera was the only absolute species-specific habitat pre- ference demonstrated in this study. Preference for that red alga by $M$. elongata ${ }^{*}$ is probably not a trophic response since Zimmermann et al. (1979) have shown that the preferred food of the amphipod are epiphytic microalgae which grow on seagrass blades and macroalgae are rarely consumed.

It is generally believed that complex habitats offer cryptic species the best source of protection from predators, and macrophyte biomass has been suggested as a good measure of habitat complexity (Heck and Wetstone, 1977). Den Hartog (1977), on the other hand, concluded that habitat complexity was a function of the gross morphology of seagrasses, and that widebladed magnosterids such as Thalassia testudinum and Zostera marina provide substrata more complex than narrow-bladed parvosterids such as Halodule wrightii and Syringodium filiforme. On the basis of habitat-selectivity experiments, it has been shown here that for epifaunal amphipods which dwell in seagrass meadows, a better estimator of habitat complexity is macrophyte surface area and that biomass or gross morphology of seagrasses may not be the most important factor in the determination of habit selection or habitat complexity.

To date, primary emphasis in studies involving seagrass epifauna have concerned the role of predators in the organization of species abundances and distributions, while neglecting concepts of habitat preference by the prey species. Although predation is probably the ultimate cause of habitat preference in seagrass associates, one must be cognizant of the importance of both habitat preference and biological interactions to gain a full understanding of distributional patterns in benthic invertebrates.

Acknowledgements. I wish to thank K. L. Heck, Jr, F. G Lewis, III, S. L. Santos, and R. W Virnstein for critical readings of the manuscript. During the course of this research, the author was supported by a postdoctoral fellowship from the Harbor Branch Institution, Inc., Fort Pierce, Florida.

\section{LITERATURE CITED}

Andrews, J. D., Hasler, A. D. (1943). Fluctuations in the animal populations of the littoral zone in Lake Mendota. Trans. Wis. Acad. Sci. Arts Lett. 35: 175-185

Barry, C. K. (1974). Role of form vision in habitat selection of the grass shrimp Hippolyte californiensis. Mar. Biol. 26: $261-270$

Connell, J H. (1972). Community interactions on marine rocky intertidal shores. Ann. Rev. Ecol. Syst. 3: 169-192

Dayton, P. K. (1971). Competition, disturbance, and community organization: the provision and subsequent utilization of space in a rocky intertidal community. Ecol. Monogr. 41: 351-389

\footnotetext{
- Zimmerman et al. (1979) identified the amphipod as Melita nitida
} 
Fenwick, G. D. (1976). The effect of wave exposure on the amphipod fauna of the alga Caulerpa brownii. J. exp. mar. Biol. Ecol. 25: 1-18

Giles, J. H., Zamora, G. (1973). Cover as a factor in habitat selection of juvenile brown (Penaeus aztecus) and white (P. setiferus) shrimp. Trans. Am. Fish. Soc. 102: 144-145

Hagerman, L. (1966). The macro- and micro-fauna associated with Fucus serratus L:, with some ecological remarks. Ophelia 3: 1-43

Harrod, Jennifer J. (1964). The distribution of invertebrates on submerged aquatic plants in a chalk stream. J. Anim. Ecol. 33: $335-348$

Hartog, C. Den (1977). Structure, function and classification in seagrass communities. In: McRoy, C. P., Helfferich, C. (eds) Seagrass ecosystems: a scientific perspective. Marcel Dekker, New York, pp. 89-122

Heck, K. L., Jr., Wetstone, G. S. (1977). Habitat complexity and invertebrate species richness and abundance in tropical seagrass meadows. J. Biogeogr, 4: 135-142

Keith, D. E. (1971). Substrate selection in caprellid amphipods of southern California, with emphasis on Caprella californica Stimpson and Caprella equilibra Say (Amphipoda). Pacif. Sci. 25: 387-394

Kita, T., Harada, E. (1962). Studies on the epiphytic communities, 1 . The abundance and distribution of microalgae and small animals on the Zostera blades. Publs. Seto mar. biol. Lab. 10: 245-257

Krecker, F. H. (1939). A comparative study of the animal populations of certain submerged aquatic plants. Ecology 20: $553-562$

Menge, B. A., Sutherland, J. P. (1976). Species diversity gradients: Synthesis of the roles of predation, competition, and temporal heterogeneity. Am Nat. 110: 351-369

Moore, P. G. (1978). Turbidity and kelp holdfast Amphipoda: I. Wales and S. W. England. J. exp. mar. Biol. Ecol. 32: 53-96

Nagle, J. S. (1968). Distribution of the epibiota of macrobenthic plants. Publ. Inst. Mar. Sci., Univ. Texas. 13: 105-144

Nelson, W. G. (1979a). An analysis of structural pattern in an eelgrass (Zostera marina) amphipod community. J. exp. mar. Biol. Ecol. 39: 231-264

Nelson, W. G. (1979b). Experimental studies of selective predation on amphipods: Consequences for amphipod distribution and abundance. J. exp. mar. Biol. Ecol. 38: 225-245

Nelson, W. G., Cairns, K. D., Virnstein, R. W. (in review). Seasonality and spatial patterns of seagrass associated amphipods of the Indian River lagoon. Florida. Bull. mar. Sci.

Norton, T. A. (1971). An ecological study of the fauna inhabiting the sublittoral marine alga Saccorhiza polyschides (Lightf.) Batt. Hydrobiologia 37: 215-231

O'Gower, A. K., Wacasey, J. W. (1967). Animal communities associated with Thalassia, Diplanthera, and sand beds in Biscayne Bay. I. Analysis of communities in relation to water movements. Bull. mar. Sci. 17: 175-210

Paine, R. T. (1974). Intertidal community structure: Experimental studies on the relationship between a dominant competitor and its principle predator. Oecologia 15; 93-120

Rosine, W. N. (1955). The distribution of invertebrates on submerged aquatic plant surfaces in Muskee Lake, Colorado. Ecology 36: 308-314

Santos, S. L., Simon, J. L. (1974). Distribution and abundance of the polychaetous annelids in a south Florida estuary. Bull. mar Sci. 24: 669-689

Sloane, J. F., Bassindale, R., Davenport, E., Ebling, F. J. Kitching, J. A. (1961). The ecology of Lough Ine. IX. The flora and fauna associated with undergrowth-forming algae in the Rapids area. J. Ecol. 49:353-368

Stoner, A. W (1979a). The macrobenthos of seagrass meadows in Apalachee Bay, Florida, and the feeding ecology of Lagodon rhomboides (Pisces: Sparidae). Ph. D. dissertation, Florida State University, Tallahassee

Stoner, A. W. (1979b). Species-specific predation on amphipod Crustacea by pinfish (Lagodon rhomboides): Mediation by macrophyte standing crop. Mar. Biol. 55: 201-207

Stoner, A. W. (in press a). The role of seagrass biomass in the organization of benthic macrofaunal assemblages. Bull. mar. Sci. 30

Stoner, A. W. (in press b). The feeding ecology of Lagodon rhomboides (Pisces: Sparidae): Variation and functional responses. Fish. Bull., U. S. 78

Stoner, A. W. (in review). The influence of benthic macrophytes on fish foraging behavior.

Stoner, A. W. (in preparation a). Community structure in the Pericarida (Crustacea) of seagrass meadows composed of three different species.

Stoner, A. W. (in preparation b). Distribution of fishes on seagrass meadows: Role of macrophyte biomass and species composition.

Van Dolah, R. F. (1978). Factors regulating the distribution and population dynamics of the amphipod Gammarus palustris in an intertidal salt marsh community. Ecol. Monogr. 48: 191-217

Virnstein, R. W. (1977). The importance of predation by crabs and fishes on benthic infauna in Chesapeake Bay. Ecology 58: 1199-1217

Young, D. K., Buzas, M. A., Young, M. W. (1976). Species densities of macrobenthos associated with seagrasses: A field experimental study of predation. J. mar. Res. 34: $577-592$

Young, D. K., Young, M. W. (1978). Regulation of species densities of seagrass-associated macrobenthos: Evidence from field experiments in the Indian River estuary, Florida. J. mar Res. 36: 569-593

Zimmerman, R. J. (1978). The feeding habits and trophic position of dominant gammaridean Amphipods in a Caribbean seagrass community. Ph. D. dissertation. University of Puerto Rico, Mayaguez

Zimmerman, R. J., Gibson, R. A., Harrington, J. B. (1979). Herbivory and detritivory among gammaridean amphipods from a Florida seagrass community. Mar. Biol. 54: $41-47$ 